\title{
METHODOLOGY FOR EXPERIMENTAL INVESTIGATIONS OF METAL FOAMS AND THEIR MECHANICAL PROPERTIES
}

\begin{abstract}
SUMMARY
This paper presents a comprehensive, systematic approach on experimental investigations of structure and mechanical properties of metal foams. Based on a thorough state of the art study, the existing solutions have been synthesised with recent developments in the discussed field to become a proposition of a possibly complete methodology for observation and testing of cellular metals. Material properties acquired in the described manners can constitute reliable reference result base e.g. for identification and verification of failure criteria. This paper describes sample preparation procedures and next discusses techniques which enable one to characterise foam structure. There are also presented procedures for determining strength limits in different load cases: uniaxial tension or compression, shear and torsion as well as multiaxial states. The tests are discussed in terms of their specific application to study cellular metallic materials.
\end{abstract}

Keywords: metal foams, tensile tests of foams, compression tests of foams, multiaxial tests of foams, shear tests of foams

\section{METODOLOGIA BADAŃ EKSPERYMENTALNYCH PIAN METALICZNYCH I ICH WEASNOŚCI MECHANICZNYCH}

Przedstawiono kompleksowe, systematyczne podejście do badań doświadczalnych struktury $i$ właściwości mechanicznych pian metalowych. Na podstawie dogłębnej analizy stanu rzeczy rozwiqzania istniejace zsyntetyzowano, uwzględniajac najnowsze zmiany $w$ omawianym zakresie tak, aby przedstawić propozycje możliwie petnej metodologii obserwacji $i$ badań metali komórkowych. Wlaściwości materiału uzyskane $w$ czasie zaproponowanych testów mogq stanowić wiarygodnq bazę odnośnych wyników, np. do identyfikacji $i$ weryfikacji kryteriów wytężenia. Opisano procedury przygotowania próbek, a następnie omówiono techniki umożliwiajace scharakteryzowanie struktury piany. Przedstawiono również procedury określania granic wytrzymałości $w$ różnych przypadkach obciqżenia: jednoosiowego rozciagania lub ściskania, ścinania i skręcania oraz wieloosiowych stanach obciażenia. Badania zostaly omówione $w$ odniesieniu do szczególnego zastosowania ich do zbadania komórkowych materiatów metalicznych.

Slowa kluczowe: pianki metaliczne, próba rozciagania pianek, próba ściskania pianek, próba wieloosiowa pianek, test ścinania pianek

\section{INTRODUCTION}

Cellular materials are a special group of materials - everything that concerns them is strictly connected to their unique structure: hexagons, dodecahedrons, bubbles, any regularly or irregularly shaped cells that pack the space. Here the structure influences behaviour more than for most other classes of materials, starting from density, weight, permeability to acoustic damping, deformation patterns, indentation resistance. Cellulars demand then special treatment, in particular - a special methodology of investigations, and such they have been receiving from scientists carefully researching secrets of these materials.

The answer to the question why reliable experimental results concerning behaviour of cellular materials are important depends of course on who is asking. From a material engineer's point of view, experimental results are the résumé chart of the material designed and produced by them. Such a confirmed characteristics allows classification of the material and often serves as a set of parameters necessary for verification in terms of a potential use. Whether the given cellular material's feature fits in terms of a particular application is of course crucial. One can easily imagine that different parameters, or even different values of the same parameter, will be important for dynamic applications, while another for static ones. On the other hand, theories of deformation and material effort and formulae resulting from them, which are the basis for the design work, are also necessarily verified experimentally. Mechanical properties, the ways how a cellular material responds to load together with its deformation manners, allow one to determine characteristic physical relationships of a material used then in structural design.

At all stages then: theoretical preparation, production and application of a cellular material experimental results are used. Yet, naturally, the scope of the present paper has to be narrower. The focus of the article is a specific sub-group of cellulars: metal foams and their structural and strength properties used for identification and verification of failure criteria. In a number of known and applied material effort criteria for cellular metals (Gibson et al. 1989; Miller 2000; Deshpande and Fleck 2000) the following particular features of a material are required: structural characteristics

* AGH University of Science and Technology Krakow, Faculty of Mechanical Engineering and Robotics, Department of Strength and

Fatigue of Materials and Structures 
including density and detailed cell topology (size, rib length, membrane thickness, connectivity etc.). Limits of strength for foams (uniaxial tensile and compressive yield points, shear strength) are also needed. Young's modulus E and Poisson's ratio $v$ complete the list. Moreover, identification of cell deformation manners played the key role in formulating failure criterion in (Gibson et al. 1989). Therefore, all listed above characteristics have to be determined in case of research which aims at verification of the existing and/or identification of a new failure criterion.

A range of studies concerning determination of structural and mechanical properties of metal foams can be found in the literature, e.g. (Blazy et al. 2004; Ruan et al. 2007; Gioux et al. 2000). From this source one learns how reported experiments were conducted and how the results were gathered in each case. Certain trends in research modes can be noticed; they have been summarised in (Ashby et al. 2000). This work in its fragment concerning experimental investigations is based on some examples from the subject literature from before the year 2000. Testing methods and data acquisition techniques have been developed in the recent decade and also many new studies have been published, adding to the reference data base. Taking this into consideration, there arose the need to revise and complement the approach to experimental investigations which serve obtaining structural and mechanical properties of metal foams. This need has been addressed in the present work. There has been done a thorough survey of the literature and based on this there have been drawn conclusions, which are presented in this article in the form of a comprehensive and up-to-date methodology for determination of structural and mechanical properties of cellular metals.

\section{SAMPLE PREPARATION AND SIZE}

If considered in a macro scale, porous metals can be assumed as uniform materials. The situation changes if the scale length becomes close to cell dimensions, which for most metal foams range from 2 to $7 \mathrm{~mm}$. Size effects are thought to occur because of a change in the constraint of the cell membranes at the boundary of a specimen as well as from stressfree cut cell edges at the surface of a sample (Motz and Pippan 2001). Additional size influence origins from the manner of a specimen being fixed in machine grips e.g. boundary stiffening resulting from glueing. For these reasons global (bulk) strength properties and moduli have to be determined using samples of appropriate sizes. Usually, specimen dimensions are described by a sample size to cell diameter ratio.

A study of size effects in ductile cellular solids was performed and is reported in (Motz and Pippan 2001; Andrews et al. 2001); authors give directions for the choice of specimen dimensions for particular types of experiments. In case of uniaxial tension/compression tests the sample should be at least 7 times the cell size. The same for twist tests. In case of shear tests it is enough if the ratio is greater than 3. For measurements of Young's modulus the ratio should be more than 7. More specific information is included below, in sections concerning each type of test.

Sample shape also depends on the kind of experiment which is performed. Generally, the rule can be assumed that cylinders or prisms of height two times larger than base length are appropriate for uniaxial strain tests. For shear tests flat rectangular specimens with thickness to base dimension ratio of about 12 would be representative (Motz and Pippan 2001; Andrews et al. 2001). Again, more specific information is included below, in sections concerning each type of tests.

As for machining of samples standard techniques would serve. Cutting with a diamond saw, with an electric discharge machine or by chemical milling causes least cell damage, while the use of a bandsaw gives a more destroyed surface. Ashby et al. report (Ashby et al. 2000) that cutting by diamond-sawing compared to by electric discharge machining does not influence values of Young's modulus and compressive strength of a closed-cell aluminium foam; however, after cutting with a bandsaw the values measured are generally slightly lower (Young's modulus was reduced by $15 \%$, while compressive strength was reduced by $7 \%$ ). If it comes to preparation of cylindrical specimens, a drilling machine is a good solution (Blazy et al. 2004) - it gives a reference revolution surface with tolerably little geometrical faults.

\section{DETERMINATION OF BASIC CELLULAR MATERIAL CHARACTERISTICS}

Before any strength tests are performed, though, it is necessary to have material's full structural characteristics: relative density, porosity, cell size, its orientation and shape, cells connectivity and their distribution (specific surface). Apart from density, which can be measured by weighing a sample of a known volume, other features require microscopy to be measured. Some ideas were presented in (Ashby et al. 2000) and are recalled below with some additional examples.

One of the basic choices is optical microscopy. It provides helpful sample images; however, metal foam needs to be fully impregnated with opaque epoxy (or equivalent) and then polished. In order to impregnate the foam sample it has to be immersed in a low-viscosity thermoset, sometimes it might be useful to add a contrast colour agent to the thermoset. Next, the polymer is forced into cells by subpressure, obtained by putting the sample in a vacuum chamber and then taking it out. For most cases conventional polishing is enough for optical microscopy. The method is preferred for closed cell materials.

For open cell metal foams a better choice would be scanning electron microscopy (SEM). This method also requires special surface preparation. 
The above discussed microscopy shows exterior of a foam sample. If data about the sample interior (bulk) are needed, the best way to acquire them is X-ray computed tomography (CT) (Huston 2011), as used e.g. in (Yoshihiko Hangai 2010; Blazy et al. 2004; Barth-Smith et al. 1998; Bastawros et al. 2000). Generally, this type of imaging approach consists in a collimated X-ray beam being transmitted through an object and its intensity measured by a detector. By comparing intensity of the source-detector pair, and using tomographic algorithms, attenuation distribution within the object is produced. Although CT gives low magnification, the resolution is usually satisfactory, since it is on the order of the cell wall thickness $(\sim 100 \mu \mathrm{m})$, but can reach even $450 \mu \mathrm{m}$. CT allows assembling of three-dimensional pictures; one of the ways to obtain it to take consecutive cross-sectional images, e.g. $1 \mathrm{~mm}$ apart along the sample length, and next reconstruct them to a $3 \mathrm{D}$ projection using tomographic algorithms (Barth-Smith et al. 1998). Another possibility to obtain a $3 \mathrm{D}$ image is to rotate a sample during CT procedures. Nevertheless, 2D cross-sectional consecutive observation is enough for evaluation of pore structures in porous aluminum compared to the method with sample rotation (Yoshihiko Hangai et al. 2010).

\section{OBSERVATION OF DEFORMATION MANNER}

How material responds to loading is crucial when foams are considered in potential applications. One of vital characteristics that conditions material's use is definitely its deformation manner. On the basis of this complex feature a scientist or a material engineer is able to:

- understand mechanisms that lie behind material's behaviour (cell collapse, plastic hinges creation, cell membrane buckling, stress concentrations, influence of local irregularities etc.);

- foresee stresses that are produced inside the skeleton due to its strain (based on constitutive relations $\left.T_{\varepsilon} \rightarrow T_{\sigma}\right)$;

- build failure criteria.

Naturally, optical methods are the first choice when one decides to follow material's deformation under loading; yet, they are of course applicable to deformation analysis of the material's surface. In case of cellular materials, especially closed cell samples, the surface is irregular with cell membranes causing shadows and locally obscuring interiors of cells. Therefore in-situ optical imaging becomes the best optical method to provide a deformation map. While some authors argue that other optical analyses methods such as moiré would not work (Bastawros and McManuis 1998), others report to have used shadow moiré (Choi and Lakes 1992) however, it was only for foams of smaller cell sizes and not for observation of the full deformation manner, but for determination of lateral strain only.

The most commonly used method is image correlation (analysis of speckle motions). In this technique there is used one or a pair of high-resolution metrology $\mathrm{CCD}$ video cameras to capture consecutive images of a surface. The surface should be sprayed with a coloured agent to enhance speckle pattern. Initial image processing consists in defining correlation regions called macroimage facets, usually around $25 \times 25$ pixels square, across the entire imaging area. The centre of each facet is a reference for measurements and is regarded as an extensometer and strain rosette. The facets are tracked in successive pictures with micro-pixel accuracy (Tyson et al. 2007). The analysis of speckle motions may also utilise subpixel interpolation methods to improve resolution (Huston 2011) and, in case of 3D correlation, also photogrammetric principles (Tyson et al. 2007). The SDA (Surface Displacement Analysis) can be carried out using e.g. commercial software (Bastawros and McManuis 1998). The analysis results with displacement vector data, which is then used to produce surface deformation maps at various stages of the loading history as well as plane strain tensor.

Strain mapping was used in e.g. studies of plastic deformation mechanisms in aluminum closed cell foams conducted and described in (Bastawros et al. 2000; Barth-Smith et al. 1998; Bastawros and McManuis 1998).

Nevertheless, when it comes to observation of deformation mechanisms inside a sample, in regions hidden behind superficial cell layers, another method answers to scientists' needs: X-ray computed tomography (CT). The method allows consecutive image capturing sufficiently fast to study cell distortion while the sample is being deformed. Exemplary use of CT to examine closed cell aluminum foam while deformation can be found in (Barth-Smith et al. 1998; Bastawros et al. 2000). Some more details about this imaging technique are written above in section 3.

\section{UNIAXIAL TESTS}

\subsection{Uniaxial compression tests}

Since metal foams are used mostly in applications where their compressive properties are essential, uniaxial tests of compression are the most common experiments conducted to assess properties of metallic cellulars.

Typically, in such tests two sample ends touch loading platens while sides of the specimen are free. In consequence, two phenomena may take place: there may occur friction between the foam and machine grips and the sample can undergo buckling. In order to avoid the influence of friction on the test results the loading plates can be lubricated with commercially available grease (e.g. as in (Gioux et al. 2000)). Greasing causes the measured compressive strength to be about $25 \%$ higher in comparison to that for dry samples (Ashby et al. 2000). Alternatively, a Teflon tape can be placed between the specimen and the loading surface, like in (Choi and Lakes 1992). As for buckling, the idea is to use samples which would have enough thickness (or area to perimeter ratio) to provide a self-constraint. Studies showed that minimum sample dimension should be at least 7 times 
the cell size (Andrews et al. 2001; Motz and Pippan 2001; Bastawros et al. 2000; Ashby et al. 2000). Height $H$ to thickness $L$ ratio should range from $H=L$ to $H=2 L$, while base dimension is assumed most often $L=10 \div 50 \mathrm{~mm}$, depending on the cell size. Concerning the sample shape, the usual choices are: square prisms (mostly for closed-cell foams) or cylinders (for open-cell foams).

Strain rates typically vary from $5 \cdot 10^{-5} / \mathrm{s}$ to $5 \cdot 10^{-3} / \mathrm{s}$. Displacement can be measured as crosshead displacement by LVDTs or directly from the sample by means of extensometers mounted on it. Lateral strain, apart from optical methods described above, may be determined using dial gauges with plate tips (Choi and Lakes 1992).

Compressive strength is taken from the stress-strain curve and is determined as the initial peak stress. In case when no initial peak stress exists compressive strength is defined as the stress at the intersection of two slopes: that for the initial loading and that for the stress plateau.

\subsection{Uniaxial tension tests}

Even though metal foams find applications where their compressive properties give best performance, it is sometimes needed to know also tensile characteristics of these materials. In uniaxial tension tests samples have usually waisted shape, though it is not necessary. In any case, the most important regions are sample ends, because they stay in contact with machine grips. In order to avoid crushing of the ends, the foam can be cast with specialist high stiffness materials (e.g. dental grade PMMA, as in (Choi and Lakes 1992)). Also, increasing of friction between the specimen and the grips is possible to be achieved by adhesive bonding or with sandpaper (Ashby et al. 2000). The cross-section can be either circular or rectangular/square. The diameter or the thickness of the cross-section should be at least seven times the cell size. ASTM E8-96a standard may constitute good reference guide for details for tensile sample machining.

Displacement can be measured similarly as for uniaxial compression tests, i.e. LVDTs or extensometers on the sample surface. Techniques for lateral strain measurements are also analogical, including optical methods or dial gauges, but this time the latter are used with round tips (Choi and Lakes 1992).

The tensile strength is taken as the maximum stress on the stress-strain curve.

\section{SHEAR AND TORSION TESTS}

Shear experiments on foams are rarely performed due to numerous technical difficulties. The problem here is low global stiffness of the cellular material and keeping of the axial alignment of the apparatus-specimen assembly. Shear strength can be measured in two types of experiments: shear tests and slightly more often performed tests consisting in twist. For multi-axial tests combining torsional and tensile loads see section 8.1 below.

\subsection{Shear tests}

Specimens used in shear tests are long thin prisms of a rectangular cross-section. The length to thickness ratio may achieve 12 in this case. Width should be ca. $50 \mathrm{~mm}$, while enough thickness $t$ is above three times the cell size, typically then $t \in(5 \div 30) \mathrm{mm}$.

There are in general two testing modes, as indicated in (Ashby et al. 2000) and used in e.g. (Blazy et al. 2004). The first method is conducted according to the standard ISO 1922:2001 (formerly ISO 1922:1981), even though the standard applies to rigid cellular plastics. Alternatively, similar testing procedures are described in ASTM C-273 standard, which also can be regarded as relevant here.

The test requires bonding the larger faces of the specimen to two stiff plates. The plates should be fixed to grips of a tensile machine and this assembly should be then put under tensile load producing shear in the foam sample (see Fig. 1).

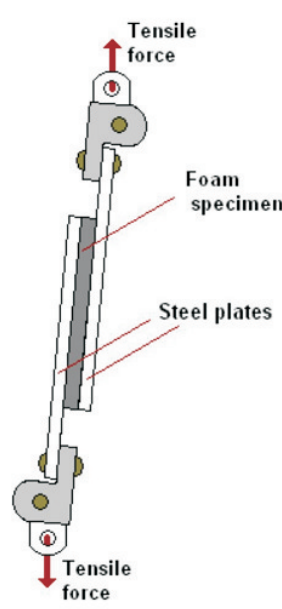

Fig. 1. Scheme of the assembly used for measurement of shear strength. The drawing is based on (Ashby et al. 2000) - the method presented in standard ISO 1922:2001/ASTM C-273

Alternatively, in the so called double-lap configuration, two specimens and three plates are used. One of the plates is put between the foam samples and the other two are glued to the external sample faces. Next this set is gripped and loaded in a tensile machine so that shear state is produced in the investigated material (see Fig. 2). Although the latter doublelap assembly provides a more uniform state of stress, sufficiently stiff plates may be problematic to design.

In both cases fixing the samples to the plates can be achieved through application of structural adhesives. Experiments of the first type were reported in (Blazy et al. 2004; Ashby et al. 2000), while the double-lap configuration in (Ashby et al. 2000).

Displacement should be read either from crosshead displacement or by the use of LVDT. Shear strength is taken as the maximum stress from the stress-strain curve. 


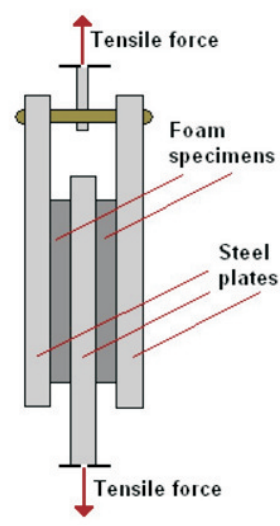

Fig. 2. Scheme of the alternative, double-lap assembly used for measurement of shear strength. The drawing is based on (Ashby et al. 2000)

\subsection{Twist method}

Specimens used in this type of experiments have a cylindrical shape. The minimum cross-sectional dimension should be larger than seven times the cell size.

Machines used for this type of measurements are tension-torsion machines.

To hold the sample in the grips similar stiffening and friction increasing methods may be used as in uniaxial tension (see sec. 5.2 above). It is very important that the axes of the sample and the machine stay collinear. The alignment of these axes can be monitored using e.g. dial gauges with a tolerance of the order of $0.1 \mathrm{~mm}$ (Blazy et al. 2004) (see Fig. 3).

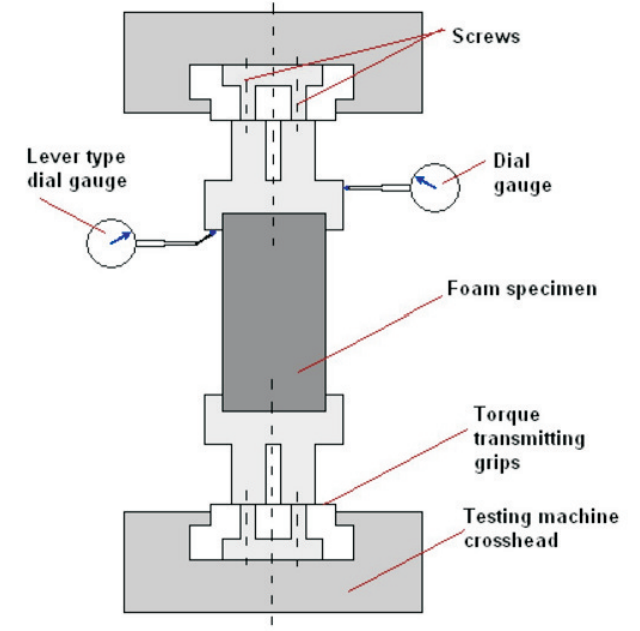

Fig. 3. Scheme of the assembly used for measurement of shear strength in torsional tests. The drawing is based on (Blazy et al. 2004)

In these tests displacement rate of an angular speed may be about $0.1 \%$ s. As for displacement and deformation measurements, this type of test requires the following conduct. Two wires should be attached to the specimen at one end and to an LVDT at the other. Change of the LVDTs position is then transformed into the angle of twist, allowing the shear modulus to be calculated (Ashby et al. 2000; Gioux et al. 2000).
Shear strength is taken as the limit of the linear elastic regime in the torsion torque/angle curve.

A complex variation of this test is when apart from the twist also axial force is added. Such a type of experiment is described in section 8.1 below.

\section{BIAXIAL TESTS}

\subsection{Biaxial compression-compression tests}

Biaxial compression-compression experiments require specimens with a cubic shape. Linear size should be minimum seven times the cell dimension. Samples may be greased to reduce friction.

Loading is applied in one direction through a regular uniaxial tension/compression machine; the other direction is subjected to load through a hydraulic jack via two pairs of plates. The specimen is loaded by first displacing one pair of plates using either the tension/compression machine or the jack, holding that displacement constant and then displacing the other pair of plates (Gioux et al. 2000; Triantafillou et al. 1989).

A typical way of conduct to measure displacement would be to determine crosshead displacement or use LVDTs for the direction of the jack load.

Ultimate strength can be defined as the peak load if one exists; otherwise, it can be assumed as the stress at which the slopes of the linear elastic and plateau region intercept each other in the stress-strain graph.

\subsection{Biaxial tension-compression tests}

Biaxial tension-compression experiments require specimens of a dogbone shape. Minimum linear dimension again should be seven times the cell size.

Tension is applied to the sample through a typical tension/compression machine. In the other direction the foam is compressed through a hydraulic jack, as described in the above section 7.1 and with more details in (Gioux et al. 2000; Triantafillou et al. 1989). The specimen is loaded in both directions sequentially. To firmly grip the sample in the tensile machine similar stiffening and friction increasing methods may be used as in uniaxial tension (see sec. 5.2 above). Analogically, greasing would be needed for the compression part of the loading system.

Displacement measurements are analogical as in compression-compression tests. Also, ultimate strength is defined similarly.

\section{MULTIAXIAL TESTS}

\subsection{Torsion and tension/compression}

Specimens used in this type of experiments have a cylindrical shape, which may be waisted as required in ASTM E8-96a. The minimum cross-sectional dimension should be larger than seven times the cell size. 
The machine type used and mounting of the specimen in it is here similar as in twist tests (see section 6.2 above). The axial load can be applied and maintained constant during subsequent torsion. Strain rates and displacement measurements are also analogical as for sole torsion and sole tension/compression tests.

\subsection{Triaxal tension-compression and compression}

The last group of experiments to be discussed in the present paper takes into account important features which are by nature omitted in the previously described examples. Triaxial tests require special apparatus - either custom built or adapted (e.g. a soil mechanics triaxial cell, see Fig. 4). In this article are presented ideas reported in (Gioux et al. 2000; Ashby et al. 2000; Ruan et al. 2007); thus, most details cited here refer to particular conditions present in the mentioned studies.

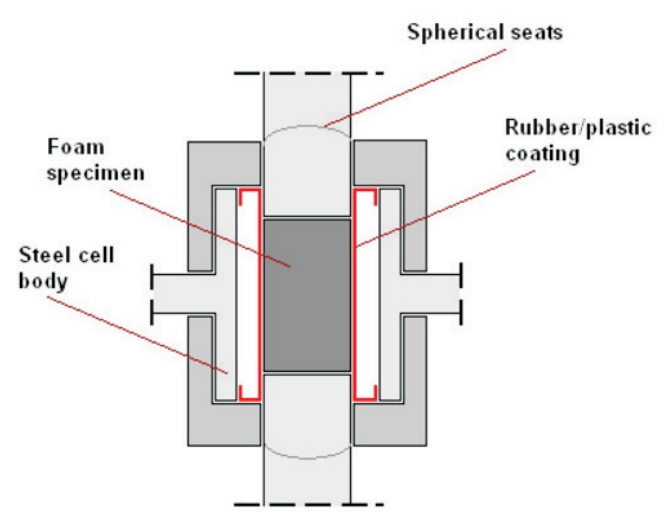

Fig. 4. Scheme of the assembly used for triaxial tests. The drawing is based on (Ruan et al. 2007)

- the method with the use of soil testing equipment

The general rule in tension/compression tests is that the specimen should be more than seven times the cell size in its smallest dimension (Motz and Pippan 2001; Andrews et al. 2001) and this also applies to triaxial experiments. Samples should be cylinders, which is conditioned by the testing apparatus shape. To isolate and seal the sample in the hydraulic cell it may be necessary to wrap the specimen in steel or aluminium film of thickness about $25 \mu \mathrm{m}$. Next, the specimen in the film may be additionally protected by a rubber coat membrane. Sealing of this assembly may be provided by wedges mounted to the sample top and bottom faces. Such a method of wrapping is reported in (Gioux et al. 2000).

There are two types of triaxial test; the first one is application of pressure in all three principal directions, while the other is application of pressure in two principal directions (radially) and tension along the specimen axis. In both cases the load perpendicular to the specimen's circumference is transferred to the sample by pressurising hydraulic fluid, which is in the loading pressure cell where the sample is placed. Axial load in case of it being compression can be added by a piston rod driven by a screw-driven test frame. If the axial direction is supposed to be put under tension, the top and bottom sample faces should be bond to attachment pieces for loading. In any case, one must respectively add or subtract the externally added axial stress to or from the hydrostatic pressure value. Also, another correction of this combined value should be made due to the presence of metal wrapping. Because of radial pressure the wrapping film undergoes plastic yield and deforms, partially being pressed into the specimen cell cavities. Due to this fact, it starts to take its part in bearing the axial load. It might be useful here to compare the results with data from uniaxial tension/compression experiments for unwrapped specimens to assess the wrapping influence.

According to guides from (Ashby et al. 2000) hydrostatic compression tests can be performed by increasing the pressure in increments ( $0.1 \mathrm{MPa}$ used there) and recording the corresponding axial displacement. Volumetric strain can be calculated from axial displacement as three times the axial strain.

Again, similarly as in most above examples material, yield strength here is defined as the peak load in the stress-strain curve. If the peak does not exist, the strength is assumed to be the stress at which the slopes of the linear elastic and plateau region intersect each other.

\section{DETERMINATION OF YOUNG'S MODULUS AND POISSON'S RATIO}

Determination of Young's modulus may be a part of uniaxial tension or compression tests. However; as is emphasised in (Ashby et al. 2000), one should note that the slope of the initial loading stress-strain graph is lower than that of the unloading curve. Therefore, measurements of $E$ should be made using data from this part of a uniaxial experiment, when the specimen is unloaded just before the stress reaches plasticity levels. This is due to the fact that in the foam there occurs localised plasticity already at stresses well below the compressive/tensile strength. In this way, the slope of the loading curve is reduced and gives falsified values of Young's modulus.

Alternatively, Young's modulus may be determined using bending tests, as in (Choi and Lakes 1992). Bending experiments can be performed by cementing a steel or aluminium arm to the top of the investigated foam prismatic sample and then applying known weights to this arm. The bottom end of the sample remains clamped or fixed to a set base surface. Next, using simple beam theory for deflection, Young's modulus $E$ may be extracted from the displacement, including corrections resulting from measured values of Poisson's ratio $v$. Poisson's ratio in this case can be observed by optical methods, like shadow moiré Deshpande and Fleck (Deshpande and Fleck 2000) advise to measure plastic Poisson's 
ratio instead of the elastic value, because the latter for aluminium foams is close to 0 and is difficult to be measured experimentally. But Ruan et al. in (Ruan et al. 2007) point out that the plastic value is also not easy to be measured, since cellular metals undergo nonuniform deformation at $20 \div 30 \%$ strains. A kind of solution here may be averaging of Poisson's ratio measurements for more samples. However, scatter data from the subject literature indicates that measurements of Poisson's ratio remain an error sensitive area of experimental practice (refer to (Onck et al. 2001) to find $v=0.33$ for Alporas foam with relative density of $8 \%$, while it is reported $v=0.024$ in (Gioux et al. 2000) for the same kind of material).

Lastly, another coefficient that can be determined in one of the experiments described above is shear modulus. It is measured from the unloading portion of the stress-strain curve in shear tests, which has already been mentioned in section 6.2 above.

\section{CONCLUSIONS}

At all stages: theoretical preparation, production and application of cellular materials, experimental results are used. Especially, structural and strength properties of metal foams are used for identification and verification of failure criteria. With this particular purpose in mind it has been decided to gather, revise and arrange information scattered in the subject literature to formulate a step-by-step, comprehensive methodology for experimental procedures which serve to finding mechanical properties of metal foams. As consequence, the present article discusses the following experimental aspects and provides up-todate references for them:

- determination of material characteristics and deformation manners with best methods to achieve it: optical microscopy, SEM, CT or shadow moiré

- uniaxial, biaxial and multi-axial tests in tension and compression as well as shear and twist tests;

- specifications for sample size and shape as well as loading apparatuses with loading modes and strain measurements.

\section{Acknowledgments}

The author would like to thank prof. R. Pecherski and $d r$ inz. R. Gieleta for their contribution and helpful remarks to this work.

\section{References}

Ashby M.F., Evans A.G., Fleck N.A., Gibson L.J., Hutchinson J.W., Wadley H.N.G., 2000, Metal Foams: A Design Guide, Butterworth-Heinemann.

Andrews E.W., Gioux G., Onck P., Gibson L.J., 2001, Size effects in ductile cellular solids. Part II: experimental results, Int. J. Mech. Sci., 43, pp. 701-13.

Bart-Smith H., Bastawros A.-F., Mumm D.R., Evans A.G., Sypeck D.J., Wadley H.N.G., 1998, Compressive deformation and yielding mechanisms in cellular al alloys determined using x-ray tomography and surface strain mapping, Acta Mater., Vol. 46, No. 10, pp. 3583-3592.

Bastawros A.-F. and McManuis R., 1998, Case study: use of digital image analysis software to measure non-uniform deformation in cellular aluminum alloys, Exp. Tech., 22, pp. 35-37.

Bastawros A.-F., Bart-Smith H., Evans A.G., 2000, Experimental analysis of deformation mechanisms in a closed-cell aluminum alloy foam, Journal of the Mechanics and Physics of Solids, 48, pp.301-322.

Blazy J.-S., Marie-Louise A., Forest S., Chastel Y., Pineau A., Awade A., Grolleron C., Moussy F., 2004, Deformation and fracture of aluminium foams under proportional and non proportional multi-axial loading: statistical analysis and size effect, Int. J. Mech. Sci., 46, pp. 217-44.

Choi J.B., Lakes R.S., 1992, Nonlinear properties of metallic cellular materials with a negative Poisson's ratio, J. Mat. Sci., 27, pp. $5373-81$

Deshpande V.S., Fleck N.A., 2000, Isotropic constitutive models for metallic foams, J. Mech. Phys. Solids, 48, pp. 1253-83.

Gibson L.J., Ashby M.F., Zhang J., and Triantafillou T.C., 1989, Failure surfaces for cellular materials under multiaxial loads-I, Modelling, Int. J. Mech. Sci. 31, pp. 635-663.

Gioux G., McCormack T.M., Gibson L.J., 2000, Failure of aluminum foams under multiaxial loads, Int. J. Mech. Sci., 42, pp. 1097-1117.

Yoshihiko Hangai, Yuichiro Ozeki, Shigehiro Kawano, Takao Utsunomiya, Osamu Kuwazuru, Makoto Hasegawa, Shinji Koyama, Nobuhiro Yoshikawa, 2010, Nondestructive Observation of Pore Structures of A1050 Porous Aluminum Fabricated by Friction Stir Processing, Materials Transactions, Vol. 51, No. 3, pp. $548-552$.

Huston D., 2011, Structural sensing, health monitoring, and performance evaluation, CRC Press/Taylor \& Francis Group.

Miller R.E., 2000, A continuum plasticity model for the constitutive and indentation behaviour of foamed metals, Int. J. Mech. Sci., 42, pp. 729-54.

Motz C. and Pippan R., 2001, Deformation behaviour of closed-cell aluminium foams in tension, Acta Mater., 49, pp. 2463-70.

Onck P.R., Andrews E.W., Gibson L.J., 2001, Size effects in ductile cellular solids. Part I: modeling, Int. J. Mech. Sci., 43, pp. 681-99.

Ruan D., Lu G., Ong L.S., Wang B., 2007, Triaxial compression of aluminium foams, Comp. Sci. Tech., 67, pp. 1218-34.

Triantafillou T.C., Zhang J., Shercliff T.L., Gibson L.J., Ashby M.F., 1989, Failure surfaces for cellular materials under multiaxial loads-II. Comparison of models with experiment, Int. J. Mech. Sci., 31, pp. 665-78

Tyson J., Schmidt T., Galanulis K., 2007, 3D Image Correlation: Measuring Displacement and Surface Strain, Sensors Magazine, June 2007.

Jaklinski B., Karus A., Kliczewska A., private communication, 2012. 